\title{
Varicela en un lactante
}

\section{Chickenpox in an infant}

\section{Sr. Editor:}

El virus varicela zoster es un virus ADN encapsulado, pertenece a la familia del virus del Herpes, es el agente causal de la varicela en los niños, y del herpes zoster y la neuralgia postherpética en adultos.

La varicela puede ser vista en infantes y en adultos no inmunizados. Esta se propaga a través de la transmisión aérea o de fómites. Se presenta raramente en niños lactantes debido a que estos se encuentran aún protegidos por la inmunidad transferida por la madre, durante su vida intrauterina y a través de la lactancia materna (1-3).

El periodo de incubación de la varicela es de 10 a 23 días desde la exposición hasta la aparición de las erupciones. El brote de las lesiones se inicia en cuero cabelludo, rostro y tronco, diseminándose posteriormente a extremidades. Generalmente es leve y autolimitado, salvo en lactantes y personas mayores de 15 años de edad, en quienes puede ocurrir complicaciones como infección cutánea bacteriana, neumonía y encefalitis (4).

Presentamos brevemente el caso de un lactante de sexo masculino de 15 meses de edad, quien presentó erupción de tipo vesicular pruriginosa de una semana de evolución, inicialmente en el rostro y posteriormente en tronco y extremidades superiores e inferiores. Concomitante tuvo fiebre de $37,5^{\circ} \mathrm{C}$, pérdida de apetito y vómitos acuosos. $\mathrm{Al}$ examen se observó erupción maculo-papular, vesículas y costras, que generaban un patrón de "cielo estrellado". Las lesiones en el rostro tenían una orientación centro facial y estaban dispersas en tronco y extremidades (Figura 1). El tratamiento fue sintomático y a los días

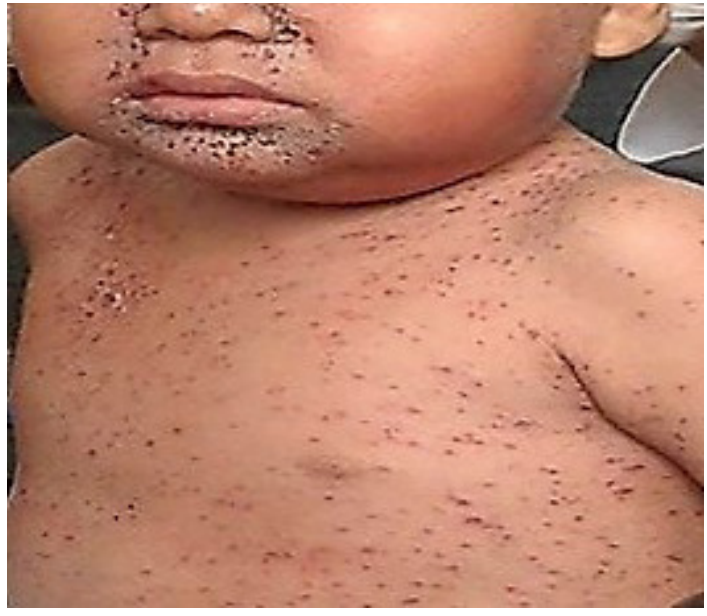

Figura 1. Lesiones eruptivas maculo-papular, vesiculares y costrosas centro facial, en tronco y extremidades.

el cuadro se autolimitó. El diagnóstico definitivo fue varicela.

En el diagnóstico diferencial se consideró la varicela congénita, pero se descartó porque no cumplió con los criterios de Alkalay et al (5), para el diagnóstico de varicela congénita: a) presencia de varicela en la gestante; b) presencia de lesiones cutáneas congénitas siguiendo dermatomas y/o alteraciones neurológicas, oculares o hipoplasia de miembros, y c) demostración de ADN viral en el niño, IgM específica o persistencia de la IgG más de 7 meses y/o la aparición de un herpes zoster en la infancia temprana.

Se informa de este caso porque la varicela en lactantes es epidemiológicamente infrecuente y puede ser indicativo de alguna inmunodeficiencia que le genere predisposición; hasta la actualidad nuestro paciente aún sigue en investigación clínica, con la

\footnotetext{
Universidad Privada San Juan Bautista. Lima, Perú.

Departamento de Dermatología. Hospital Nacional Hipólito Unanue. Lima, Perú.

Estudiante de Medicina Humana;

Médico Dermatólogo
} 
finalidad de poder brindar un tratamiento eficaz y oportuno y así evitar futuras complicaciones.

\section{Mayron D. Nakandakari 1,a, Dyanne N. De La Rosa ${ }^{1, a}$, José Arias ${ }^{2, b}$}

\section{Correspondencia:}

Mayron David Nakandakari Gómez

Mz. A5 Lot. 10 AAHH. Cerro Candela. San Martín de Porres. Lima, Perú.

Correo electrónico: mdngmedicinaupsjb@hotmail. com

Teléfono:(51) 1 796-3569 (51) 959-727503

\section{REFERENCIAS BIBLIOGRÁFICAS}

1. Verd S, López E. Management of chickenpox with frozen mother's milk. J Altern Complement Med. 2012; 18(8):808-10. doi: 10.1089/acm.2011.0472

2. Bhardwaj A, Sharma P, Sharma A. Neonatal varicela: A case report. Australas Med J. 2011; 4(6):291-3. doi: 10.4066/AMJ.2011.682

3. Paul SP, Zengeya ST, Hicks SS. Neonatal varicela infection: are webeingfalselyreassuredby a maternal history of chickenpox? Br J Hosp Med. 2013; 74 (6): 352-3.

4. Fernández-Quiñones Y, Sánchez-Linares V. Herpes zoster en un lactante. Dermatol Rev Mex. 2015; 59:39-42.

5. Alkalay L, Pomenrance J, Rimoin L. Fetal varicela syndrome. J Pediatr. 1987; 111:320-3.

Recibido: 25/04/2018 